\title{
Private Voluntary Support to Public Universities in the United States: Late Nineteenth-century Developments
}

Received (in revised form): June 3, 2005

\begin{abstract}
Samuel G. Cash
Samuel G. Cash is Vice President for Institutional Advancement at Truett-McConnell College in Cleveland, Georgia. He holds degrees from Berry College, Florida State University, and the University of Georgia. His research interests include higher education philanthropy, finance, and leadership. His dissertation "Private, Voluntary Support of Public Research Universities in the United States: 1785-1958" was the cowinner of the 2002 John Grenzebach Research Award for outstanding research in educational philanthropy sponsored by the Council for the Advancement and Support of Education (CASE). Dr. Cash has served various other nonprofit organizations and is an alumnus of the accounting firm PricewaterhouseCoopers. He is a certified public accountant.
\end{abstract}

\begin{abstract}
The early history of private support to state universities in the United States followed an inconsistent pattern. From the chartering of the first state university in 1785 through the antebellum period, state universities followed patterns of raising support established by the colonial colleges and relied on a combination of public and private support. This inconsistent pattern improved after the Civil War due to the intersection of powerful social and political forces. This study explores this second stage in the history of private voluntary support of public research universities in the United
\end{abstract}

Samuel G. Cash:

Vice President of Institutional Advancement

Truett-McConnell College

100 Alumni Drive

Cleveland

GA 30528, USA

Phone: +1 7068652134

Fax: +1 7062191744

Email: scash@truett.edu
States during the latter part of the nineteenth century. During this period several factors affected the state institution's ability to attract private funds. These factors include changing social and educational aims, a redefinition of stewardship, and the changing Federal interest in higher education. The emergence of a more responsive American university in the late nineteenth century further stabilized levels of support and created a more consistent pattern of fund raising for state colleges and universities.

\section{Keywords:}

fund raising history, public higher education, voluntary support

\section{Introduction}

As noted in an earlier article, inconsistency marked the patterns of support from the time of the chartering of the first state university in 1785 through much of the antebellum period in the United States. ${ }^{1}$ Most of these early 
state universities struggled to obtain needed support from their states and resorted to various combinations of public and private support. This struggle revealed certain issues peculiar to the funding of higher education not unlike issues today. Institutional leaders attempted an understanding of the motives for giving; however, they were not able to focus on developing regular sources of private support probably due to regular conflicts with their states over funding. In terms of support, the early state institutions did little more than resemble the sectarian institutions of the day and, perhaps to a greater extent, the colonial colleges. As these institutions progressed, private support did not abate through periods of unstable state support. Private support through subscriptions and in-kind gifts stabilized an otherwise precarious fiscal status for these institutions as the forerunners of alumni associations, and "town-and-gown" relations gave state institutions a reasonable foundation in the realm of private fund raising.

After the Civil War, the patterns of support to state universities improved due to the intersection of powerful social and political forces. The rapid growth of industrial wealth, the move toward urbanization and westward expansion, the Protestant culture of American exceptionalism, and a secular understanding of the aims of education strengthened personal and state allegiances to the colleges and universities. ${ }^{2}$ This was to be the age of the American university with its purposes of instruction, research, and service clarified through a utilitarian, or practical, education. As late nineteenthcentury higher education became utilitarian some institutional leaders of the day began to see higher education as an equal partner in economic development with government and industry. Throughout this period the states increased their funding of higher education and its regularity while the pattern of voluntary support to the state institutions remained unstructured. The wealth to support private giving was available as entrepreneurial profits created personal fortunes that could support philanthropy. At this time, though, the changing social and educational aims, a redefinition of stewardship, and the changing Federal interest in higher education all may have affected the state institutions' ability to attract private funds. This paper explores these influences on raising private voluntary support at state universities after the Civil War and through the late nineteenth century.

\section{Intersecting Social and Educational Aims}

The changing educational aims of the time enabled the development of a more modern conception of a university in the United States. The emergence of the truly American university in the latter part of the nineteenth century was essentially one of assimilation to the changing environment of the time. ${ }^{3}$ Institutional changes affected the levels and types of support needed to sustain these institutions. One such change was accessibility. The universities of this era became more accessible to the various segments of American society, resulting in an increased demand for higher education. The need for research in areas which would benefit industrial society produced an even greater demand for funds. The rise of science, engineering, and agricultural science and related research required funds to maintain the trend. Additionally, the professionalization of law, medicine, and 
business spurred the need for better equipped facilities and qualified instructors. Another change creating a need for funds was the addition of administrators at these institutions who had a more secular bent toward running an institution. Administrators characteristically thought in terms of institutional management; this included a concern for budgets, public relations, institutional statistics, and institutional standards. The administration's attention to organization planning had the effect of isolating the president from faculty ways of thinking. As a result, presidents focused on financial and organizational issues which provided growth and stability for the institution. Laurence Veysey suggests that the "progressive administrator ... sought eagerly to broaden the base of his institution's support." "4 The administrators realized the importance of private support and for building coalitions at the statehouse for improving state funding. The rise of alumni groups, clubs, fraternities, and other campus groups created another avenue for private support. Additionally the rise of collegiate athletics contributed to the feverish need for adequate funds for facilities and staff.

The strengthening American economy of the latter part of the nineteenth century helped change American society and meet these new needs of the university. The economic expansion from the Civil War to the end of the nineteenth century enabled the expansion of higher education. One factor for this trend was significant increases in population. From the year 1850 to 1900 the total population of the United States increased from near 23 million to over 76 million. ${ }^{5}$ The most dramatic increases in population during this period were located in the South, where the population increased from 8.9 million to 24.5 million, and in the North Central states which increased from 5.4 to 26.3 million. ${ }^{6}$ A trend toward urbanization was evident in that the number of incorporated towns and cities of over 2,500 increased from 392 in 1860 to 1,737 in $1900 .^{7}$ Despite the economic setbacks of the Civil War, which drew capital away from industry, industrial production soared and the number of nonfarm business concerns grew from near 204,000 in 1857 to 427,000 by 1870 and $1,174,000$ by $1900 .^{8}$ Despite certain economic declines throughout some of the years of the latter half of the nineteenth century, industrial and agricultural production increased through most of these years. Other important economic influences on social and educational change during this period include the growth of railroads, the growth of a petroleum industry, and advances in technology and innovation. Additionally through these years the federal government, due to the foresight of certain political leaders, began to see its economic role as a nonmarket influence to help control growth.

\section{The Redefinition of Stewardship}

The creation of wealth in the late 1800s, a result of the economic expansion of the time, enabled a level of giving to higher education never before achieved; however, it would appear that the state universities were not poised to obtain a great portion of these great fortunes. Although one might blame the leaders of the state universities for not having clearly articulated ideas about financial support at this time, focusing more on increasing legislative support instead, there were some changing cultural values and a redefinition of stewardship which influenced inconsistent levels of private support to public institutions. 
One cultural change which developed alongside the extraordinary economic growth of the time was the emergence of a "bourgeois culture," a culture which centered on middle-class values and ideals. ${ }^{9}$ These values, including easy access to education, the encouragement of social mobility, and the promotion of personal freedoms, fueled nineteenth-century industrialism but, perhaps more importantly to higher education, created a need for a type of education which would achieve these values. Due to the increase in consumer demand and trends toward urbanization, entrepreneurial activity reacted to the marketplace and milliondollar fortunes were created. As "selfmade" men achieved these fortunes a concomitant change occurred with ideas of stewardship.

Stewardship, with its religious overtones, now took on a secular definition. ${ }^{10}$ The contrast between these changing conceptions are seen in the philanthropic philosophies of two multimillionaires of the time, John Rockefeller and Andrew Carnegie. The conservative, religious conception of stewardship undergirded Rockefeller's benevolence. A devout Baptist, Rockefeller held to the old-fashioned religious doctrine of stewardship and felt the burden and responsibility of wealth. Rockefeller felt that his wealth was from the "good Lord" and was given for a specific purpose. ${ }^{11}$ Further, he felt the responsibility to handle it with care. In contrast, Andrew Carnegie's views epitomized the more secular conception of stewardship referred to as the new "gospel of wealth." Although there were religious overtones to Carnegie's gospel, "... he did not believe that under modern conditions much good could be accomplished by imitating the life or methods of Christ." 12 Carnegie referred to philanthropists as "administrators of surplus wealth" who had it in their power to provided lasting benefits for the poor and weak through their benefactions. ${ }^{13}$ This new conception of stewardship is articulated in an essay by Carnegie on the "Administration of Wealth":

This, then, is held to be the duty of the man of wealth: To set an example of modest, unostentatious living, shunning display or extravagance; to provide moderately for the legitimate wants of those dependent upon him; and after doing so, to consider all surplus revenues which came to him simply as trust funds, which he is called upon to administer, and strictly bound as a matter of duty to administer in the manner which, in his judgment, is best calculated to produce the most beneficial results for the community.... ${ }^{14}$

Carnegie's redefinition of stewardship fit in neatly with the rise of a bourgeois culture fixed on getting ahead. Carnegie further supported giving to higher education as a need of utmost importance, in particular supporting those institutions already in existence:

... let us endeavor to present some of the best uses to which a millionaire can devote the surplus of which he should regard himself as the only trustee. First. Standing apart by itself there is the founding of a university by men enormously rich, such men as must necessarily be few in any country.

It is reserved for very few to found universities, and, indeed, the use for many, or perhaps, any, new universities does not exist. More good is henceforth to be accomplished by adding to and extending those in existence. ${ }^{15}$ 
Religious leaders responded adversely to the philanthropy of the millionaires of the period. One illustrative response by Washington Gladden, a Congregational minister, denounced the ways of trade and referred to the self-made men as "robber barons" and "pirates of industry." The money they gave, according to Gladden, was tainted and he asked whether a church or university could accept it without indirectly condoning the standards of the donor. ${ }^{16}$ Nevertheless, Americans remained preoccupied with the millionaires and their uses of great wealth. This preoccupation is reflected in a report from the New York Tribune in 1892 listing 4,047 men and women reputed to be millionaires. ${ }^{17}$ Other articles appearing subsequent to this suggested that some of the millionaires were not givers, thus calling into question the reputation of the wealthy. ${ }^{18}$ Of those who were givers, studies indicated that education received near a third of their total giving, that those who had no more than secondary education gave more than those with college degrees, and that self-made men were more philanthropic than those inheriting their wealth. ${ }^{19}$ As a strengthening economy and bourgeois culture fueled the creation of wealth, there still appeared to be no effective method for organizing and conducting philanthropy to higher education at the state universities, the institutions which would seem to be in a position to benefit from changing conceptions of stewardship from a religious to a secular motive.

\section{The Changing Federal Interest in Higher Education}

Another factor affecting patterns of support to the state universities was the changing Federal interest in higher education during the late nineteenth century. The passage of the Morrill Act in
1862 marked the beginning of a period of increasing Federal support for higher education. Named after Vermont representative Justin Morrill, this act of Congress provided federal lands of 30,000 acres for each senator and representative to each state for establishing

... at least one college where the leading object shall be, without excluding other scientific and classical studies, and including military tactics, to teach such branches of learning as are related to agriculture and the mechanic arts, in such manner as the legislatures of the states may respectively prescribe, in order to promote the liberal and practical education of the industrial classes in the several pursuits and professions of life. $^{20}$

Through this original Morrill Act, 48 state colleges and universities had received aid by 1889 , of which 33 had not previously existed. ${ }^{21}$ In what has been considered the wisest disposition of the land scrip, in 13 states, including Wisconsin, Minnesota, Missouri, Georgia, North Carolina, and Tennessee, the land scrip went to institutions already in existence. ${ }^{22}$ In 20 states the Act prompted a separate college of agriculture and mechanic arts which competed against the state university. ${ }^{23}$ The effects on financial support to the state universities were positive.

Communities eager to attract the new federally funded state institutions rallied support from individuals often in the form of subscriptions of cash and noncash gifts such as land. Although the movement toward a practical education from a classical liberal arts education may have influenced increasing support, state legislatures may have been forced to consider increasing their levels of support 
in order to keep the funds created from the federal land grants and to satisfy constituents from communities in support of the nonsectarian institutions. ${ }^{24}$ This trend continued as state support stabilized after the passage of the Hatch Act in 1887 and the second Morrill Act in 1890 probably due to guaranteed annual federal appropriations. ${ }^{25}$ Despite the stabilization, the land-grant institutions through the latter part of the nineteenth century suffered from slow growth in enrollments, high attrition, low salaries, overworked professors, and primitive facilities. ${ }^{26}$ States still appeared unsure of how to raise necessary tax support for a state institution when other organizations needed monies as well. Andrew D. White, colleague to Ezra Cornell while in the New York Legislature, argued persuasively for state support of institutions of higher learning:

Talk of economy! Go to your state legislatures-what strange ethics in dealing with the public institutions! If asked for money to found an asylum for idiots and lunatics or the blind or the deaf and dumb, you will find legislatures ready to build palaces for them. Millions of dollars are lavished upon your idiots and deaf and dumb and blind and lunatics. Right glad I am it is so; but when you come to ask aid even in measured amounts for the development of the young men of the State, upon whom is to rest its civilization, and from whom is to flow out its prosperity for ages to come, the future makers of your institutions and laws, how are they to be left to the most meager provision during all their preparation? ${ }^{27}$

Of course Ezra Cornell persuaded the state of New York to allocate its land scrip to a private institution named after him to be founded through his donation of half a million dollars in Western Union stock and a site for the institution to be led by Andrew White. ${ }^{28}$

\section{Examples of Trends in Raising Private Support}

The origins of the state universities in the latter half of the nineteenth century provide examples of the trends of support during this period and the issues surrounding this support. In the new territories and states of the West the involvement of various citizens in advancing educational opportunities resulted in initial foundations of support. In Washington a primitive territorial university was opened in a building on the outskirts of the village of Seattle in 1861. Reverend Daniel Bagley, a Methodist minister seeking to escape the sectarian rivalries in Oregon, moved to Seattle and began promoting the advantages of having a nonsectarian university in the community. ${ }^{29}$ Through Bagley's promotion villagers Arthur and Mary Denny donated eight acres of land which was followed by a gift of two additional acres from Charles and Mary Terry and Edward Lander. ${ }^{30}$ As a university in name only, the school had very few students at the collegiate level and would grant its first collegiate degree 25 years later. $^{31}$

While sectarian rivalries possibly delayed the founding of the public university in Oregon, private gifts and publicity initially played important roles. In 1872 the revival of interest in the territorial university endowment from the Northwest Ordinance of 1781 led to the question of the need for a territorial university. There were already seven chartered institutions, all church-related, in the territory, and all lacked adequate funds. A legislative struggle ensued 
between the existing colleges and a delegation of citizens from Eugene intent on annexing the original university endowment for a newly created institution. The citizens of Eugene shrewdly formed an association with capital stock of $\$ 50,000$ that was to become available to purchase a site and erect a building if the legislature awarded the endowment to Eugene. This Lane County delegation obtained the necessary support from legislators and a bill approving the location of the state university was signed by the governor in 1872. ${ }^{32}$ Following approval, the Lane County delegation formed a committee to solicit subscriptions. Seventeen acres were donated for the original site of the university while the financing was obtained through a $\$ 30,000$ local bond issue supported by $\$ 20,000$ in private subscriptions. Letters published in the Oregon State Journal promoted a positive impression of the potential impact of the forthcoming university on the community:

Friends of the university tried to meet the opposition by showing the large sum of money, $(\$ 150,000)$, which would be brought into Lane County by the establishment of the university. The new foundation would also attract wealthy families to the county who would help pay the taxes and put money into circulation. It would also increase the value of farm land at least two and one-half dollars per acre. This for 200,000 acres would make $\$ 500,000$ of increased valuation of real estate. When once inaugurated, the university would bring into the community 500 new persons a year. It would also exert a wonderful power in elevating the moral standards and improve the condition of the people. $^{33}$
In Colorado, Governor Edward McCook signed a territorial bill in 1870 to establish an agricultural college in order to receive the land grant offered through the Morrill Act of 1862. Larimer County contributed 80 acres after a citizen of Fort Collins, Mr. Robert Dazell, deeded 30 acres to establish a site for the new college. The Territorial Legislature agreed to appropriate $\$ 1,000$ in 1874 if the Trustees could raise a matching sum. Local citizens, businesses, and the Grange raised the matching funds. The group of farmers from the Grange showed their continued support through holding farm events on the university's land and constructing a small brick building. Colorado Agricultural College, later Colorado State University, welcomed its first students in September of 1879. ${ }^{34}$

A similar start for the University of Colorado led to difficulty with initial subscriptions. Land donations in 1872 from certain citizens of Boulder provided the lead support for the university which would officially open in 1876 . These gifts of land from three couples totaled over 130 acres and prompted the Board of Trustees to appoint a committee of seven to solicit donations. This initial drive for private funds raised $\$ 1,135$ in subscriptions and cash, apparently an amount far short of funding the construction of the first building. A possible reason for this shortfall in private support was a competing drive for funds from citizens to help construct a railroad between Boulder and Denver. Undeterred, J. P. Maxwell, the member of the House of Representatives from Boulder, introduced a bill on January 25, 1872, for appropriating $\$ 15,000$ of territorial funds to the university. This initial bill failed but was reintroduced after petition by the Board of Trustees in January of 1874 , only this time requesting $\$ 30,000$. The 
territorial legislature agreed to $\$ 15,000$ only if the citizens of Boulder could raise a matching amount. Sufficient pledges were raised in dramatic fashion by the speaker of the House, Captain David H. Nichols, who rode on horseback from Denver to Boulder and back in an overnight trip to gather the pledges for the passage of the bill. Although pledges were gathered there still remained some uncertainty regarding their collection. This uncertainty is reflected in the Trustees' enlistment of prominent citizens from Boulder to solicit donations as they traveled in the Eastern states. Included among these citizens were the Presbyterian and Episcopal ministers; their attempts were apparently unfruitful. In November of 1874 the young banker, George Corning, led a vigorous campaign for the Trustees to secure the subscriptions necessary for receipt of the territory's $\$ 15,000$ appropriation. To avoid the loss of the appropriation, the Trustees arranged for a bank loan to cover the $\$ 15,000$ needed from Boulder. The state auditor refused to release the legislative funds on the grounds that this loan was not valid as the matching donations. The Trustees then mounted another effort to raise the matching funds and by the spring of 1875 had raised over $\$ 16,000$. $^{35}$

Among the existing and newer state universities of the Midwest similar themes regarding private support developed during the late nineteenth century. In Michigan a state agricultural college had already been founded in 1855 prior to US Congressman Justin S. Morrill's plea for the land-grant endowment in 1858. Morrill actually used Michigan's agricultural college as a successful example of the type of agricultural college the federal government should support through its land grants. As early as 1849 E. H. Lothrop, the orator for the first
State Fair, decried the lack of agricultural training in the young state in an address to an audience at the Fair. One observation of the effects of this speech indicates an awareness of the need for private support but a realization that few people in the state had significant enough wealth at the time to make this a possibility. ${ }^{36}$ The state legislature issued an unfruitful plea to the US Congress for 350,000 acres of federal land in 1853 for the purpose of developing agricultural education. In 1855 the state legislature approved a bill to create the agricultural college and authorized payment of 15 dollars per acre for the site. After competition from several communities, Lansing won out with its cheaper land prices. Several farms and tracts of land were offered but A. R. Burr's 677-acre farm was favored by the committee charged with locating a site.

Ohio's bid for a state agricultural and mechanical college began in 1870 and followed a similar pattern of competition from communities. The original Board of Trustees reviewed the initial offers of land and money from various communities. Appointed to their positions by Governor Rutherford B. Hayes, the trustees came from each of the Congressional districts of the state and sought the best interest of their district by soliciting donations from their communities to attract the new college. An example of an appeal by trustee Joseph Sullivant to the citizens of Franklin County illustrates the use of the power of his position coupled with an earnest plea for the cause of higher education and the positive effects on the community:

The advantages accruing to any county which secures this institution are so obvious that I need not here present any arguments to prove them. Is it not 
proper that the citizens of Franklin County should move immediately in behalf of their own interests? Shall we, by indifference or supineness, neglect this opportunity, and permit the superior liberality and enterprise of another county to carry away a prize which we can and ought to preserve for ourselves? May I not appeal with confidence to the farmers and mechanics of Franklin County, for a hearty and generous support of an enterprise which is intended to give public recognition and dignity to their professions, and which is to be carried forward in such a manner as to assist in developing all the great industrial interest of the State? I respectfully suggest that a meeting of all parties interested be called at an early day, to consider the important subject here presented. $^{37}$

Sullivant placed further weight on his appeal by closing as follows: "It is evident that without the liberal cooperation of the people of the State, the intentions of Congress and the Legislature cannot be realized." 38 The people from four counties of the state cooperated by actively competing for the college. Each offer combined plans for issuing local bonds with pledges of money and land from prominent citizens. Columbus and Franklin County won the bidding with their offer of $\$ 328,000$, including private contributions of $\$ 28,000$ and $\$ 300,000$ in seven percent bonds; the $\$ 28,000$ was used as a down payment on a 327-acre farm which would serve as the site for the college. ${ }^{39}$

The promise of federal lands under the Morrill Act prompted the founding of the University of Arkansas in 1871 with a combination of state and private support. A committee appointed to select a site considered the competing bids for the university. Attracted to a "magnificent homestead" of 160 acres in Fayetteville owned by William McIlroy, the committee approved its purchase for $\$ 12,000, \$ 1,000$ of which was paid by Fayetteville citizens. ${ }^{40}$ In neighboring Kansas, competing communities also sought subscriptions to attract a "Free State College" in a politically divided state. Governor Thomas Carney in 1863 expressed his desire to the legislature for creating a university which would make them eligible for the federal land grant. Funds yet to be raised of $\$ 15,000$ were offered from Lawrence while Emporia pledged 80 acres of land after the state passed a bill for creating the university. ${ }^{41}$ A house committee recommended the Emporia offer which then prompted the Lawrence supporters to furiously raise the $\$ 15,000$ in 10 days. The citizens then added to their offer 40 acres to secure their plea for the university. The $\$ 15,000$ included a promise of $\$ 10,000$ from wealthy Massachusetts manufacturer Amos Lawrence if town leaders raised the additional $\$ 5,000$. $^{42}$ Citizens with connections in the East, such as a Mrs. Emily P. Burke, continued seeking donations from influential Easterners although it is not certain how fruitful these solicitations were. ${ }^{43}$

Illinois's initial call for support of a state university resulted in a unique proposal in 1855. The plan included a form of joint sponsorship of a university by the state and a self-perpetuating board of 12 members who were well-known business leaders. The idea for financing the venture included funding from three sources: a private fund of $\$ 20,000$ to be raised by the board, a state normal school fund, and a state university fund. This plan further stipulated state funds to be paid out up to $\$ 20,000$ only if the board 
were successful in raising their donations; this would continue in $\$ 10,000$ increments until the state's college and seminary funds created from federal land grants of the Northwest Ordinance were exhausted. ${ }^{44}$ Although creative, this proposed plan failed to receive its endorsement from the legislature of 1955. After the passage of the Morrill Act in 1862 the plan for the state university gathered momentum. Several communities desired the university, as demonstrated through promises of land and money. By 1867 the list of competing communities included Bloomington, ChampaignUrbana, Jacksonville, and Lincoln. Champaign-Urbana was able to successfully offer a large building already constructed and used by an educational institute on a 140-acre farm.

In the East, the pattern of raising private support for newly formed universities was repeated. For example, in Pennsylvania the predecessor to Penn State University, the Farmers' High School, received approval in a bill signed by Governor William Bigler in 1854 . Trustees searched for a site for this institution and considered proposals from individuals in five counties willing to donate or sell 200 or more acres. James Irvin, a businessman with success in iron furnaces, forges, and rolling mills, offered any one of three 200-acre tracts from his extensive land holdings in Centre County. After two trustees offered to help Irving raise $\$ 10,000$ from local citizens to combine with the land offer, an isolated site near the Nittany and Penn Valleys was accepted. Following acceptance the trustees mounted another campaign to raise funds. In addition to the $\$ 10,000$ in subscriptions, the trustees obtained a grant of $\$ 10,000$ from the state agricultural society and accepted a $\$ 5,000$ bequest from wealthy Quaker merchant
Elliott Cresson of Philadelphia. The trustees implicated themselves further with the institution by donating personal funds for the construction of the first building. Spurred on by the passage of the Morrill Act, the institution changed its name to the Agricultural College of Pennsylvania and successfully obtained the endorsement of the state legislature to become the recipient of the federal land grant. ${ }^{45}$

Several years later, Georgia's bid for an engineering and technology college led to combinations of public and private offers of support from communities. Stimulus for the institution came from the "New South Creed," a social, economic, and intellectual movement of the 1870s and 1880 s in the South. Benjamin H. Hill, a proponent of this movement who served as a US Senator, spoke to the Alumni Association of the University of Georgia in 1871 regarding the need for a more practical education which would aid the South in moving away from its dependence on slavery and enable the South to compete equally with the North in industry. Hill's remarks prompted consideration for "schools of agriculture, of commerce, of manufactures, of mining, of technology, and in short, of all polytechnics. ${ }^{, 46}$ In the early 1880 s Henry Grady, the influential editor of the Atlanta Constitution, joined the plea for a New South in his editorials promoting education and economic development. Macon industrialist John F. Hanson, and Nathaniel E. Harris, a candidate for the state legislature, took up the cause for a state polytechnic college in 1882 through an editorial in Hanson's newspaper, the Macon Telegraph and Messenger, lamenting the scarcity of skilled labor for manufacturing in the state. Harris was elected to the legislature later in the year and introduced a successful resolution in the legislature for a school of technology. 
A committee was formed to travel to the North and inspect several engineering schools. The result was a report "placing technical education in the context of other ways of stimulating industrial and economic development." 47 This committee determined the need for $\$ 65,000$ to start such a school and provide it with the proper equipment and facilities. After this report and ensuing debates over issues through the editorials of the Atlanta Constitution, the bill for the proposed school failed in 1883 but was taken up again in 1885. This time an editorial in the Atlanta Constitution urged doubters to support the bill for the school; the bill was passed with the approval of $\$ 65,000$ in unappropriated funds if available. A commission composed of members whose communities would be likely candidates for the school was created. Macon, Atlanta, Penfield in Greene County, Athens, and Newton County each received representation on the commission. Competing bids from each of the locations included various combinations of public and private support. After a series of private balloting, the school later to be the Georgia Institute of Technology was awarded to Atlanta with its bid of $\$ 50,000$ from the city, $\$ 20,000$ from private citizens, a choice of three sites valued at $\$ 10,000$, and an annual annuity of $\$ 2,000$ per year for 20 years. ${ }^{48}$

Bequests suggestive of the growing availability of wealth during the latter part of the nineteenth century provided additional funds for some state universities. As the state legislature in Virginia debated over the disposition of the land grant fund in 1869 , the University of Virginia received a bequest of $\$ 100,000$ from the estate of Samuel Miller of Albemarle County to establish a department of scientific and practical agriculture. This bequest combined with an ensuing gift from Thomas Johnson of Augusta County which sparked a request from the University to the state for the land-grant money. The University's request prompted competing responses. For example, Washington College and its president Robert E. Lee formulated a plan for a school of agriculture and obtained financial support from farm equipment inventor and manufacturer Cyrus McCormick; McCormick's \$10,000 contribution was less than hoped. Another plan included a joint venture for an agricultural institute between Washington College and the Virginia Military Institute. The smaller colleges in the state also maneuvered for the landgrant fund and in doing so exerted a divisive effect in the state legislature. The bill, which was finally passed on March 19,1872 , gave one-third of the land grant to Hampton Normal and Industrial Institute and two-thirds to the Preston and Olin Institute, which relinquished its charter and donated its property to the state. The newly organized Virginia Agricultural and Mechanical College of Montgomery County relied initially on additional private gifts from local citizens near $\$ 20,000$. $^{49}$

In South Carolina a bequest to the state produced a different result. At first the availability of land-grant funds initiated a College of Agriculture and Mechanics which would be a part of the existing state college. This emphasis on agricultural education was not received well by the students, as demonstrated by their lackluster participation in the mandatory farm labor. ${ }^{50}$ Certain individuals took up the cause for a separate agricultural institution elsewhere, including farmer Benjamin Tillman of Edgefield. Tillman's cause received momentum when in 1888 Thomas G. Clemson died and left his Fort Hill estate 
of 814 acres and near $\$ 80,000$ to the state for establishing an agricultural college separate from the existing state college. Incorporated in Clemson's bequest, seven of a 13-member board of trustees were named to protect against political interference. The fact that the existing state college had a school of agriculture presented a problem for the state's acceptance of the bequest; Benjamin Tillman attacked the adequacy of this school in an effort to draw the Morrill and Hatch land-grant funds away from the state college. Debates occurred in the legislature over this issue. During 1888 Tillman rallied support for the Clemson bequest and in 1889 the governor signed a bill accepting the bequest. Another bill followed to establish the Clemson Agricultural College and to award the Morrill and Hatch funds to this institution. In a manner which would seal the fate of both the Clemson Agricultural College and South Carolina College, Tillman ran for and was elected governor in $1890 .^{51}$

Back out West, the University of California received many notable gifts through its initial years indicative of the available wealth in the state at the time. The fourth campus building at Oakland, a gymnasium, was constructed from a private gift by A. K. P. Harmon in $1879 .{ }^{52}$ A pioneer citizen of San Francisco, James Lick, invested wisely and became a millionaire near this time. Lick decided to build an observatory with the world's most powerful telescope in 1873. By its completion in 1888 , the property was deeded to the university. ${ }^{53}$ The university received as a gift the building and facilities of the Toland Medical College in 1873 from Dr. Hugh Toland in San Francisco. ${ }^{54}$ The fine arts benefited from the gift of the Mark Hopkins mansion in 1893. Hopkins, of Central Pacific Railroad fame, spent between two and three million dollars on the mansion on Nob Hill in San Francisco and left it to his wife upon his death. Edward F. Searles later married the widow and inherited the mansion upon her death. Searles gave the mansion to the university on condition that it be used exclusively for the fine arts. ${ }^{55}$ In 1894, J. Clute Wilmerding, a wealthy San Francisco liquor merchant, left a bequest of $\$ 400,000$ to the university to establish a trade school for boys. Although the trade school was not a part of the mission of the institution, the Regents felt such a large gift could not be turned down. ${ }^{56}$ Phoebe Hearst, widow of the senator and mother of publisher William Randolph Hearst, contributed $\$ 200,000$ to fund a competition for an architectural plan for the Berkeley campus in 1896. Hearst's gift and the architect competition drew international attention to the university and made possible the orderly development of the campus. ${ }^{57}$

\section{Conclusion}

In Jesse Sears's systematic study of philanthropy and higher education an important question is posed regarding the situation of the state college and university of the late nineteenth century: "Should the State, or private and philanthropic enterprise, determine the character and amount of higher education?" 58 The answer seemed to be a combination of both. Although the pattern of private support to state universities during the latter part of the nineteenth century lacked regularity, the reliance on private gifts appeared to increase at a time that institutions responded to changing social and educational aims. Much like the antebellum period, but perhaps at a greater level, citizens from communities banded together to donate cash and 
noncash items as an incentive to bring the institution to their community. Economic advances during this time enabled a higher level of private giving to higher education than ever before. Increasing numbers of bequests to the state institutions attest to the economic growth of the nation. Combined with the changing federal interest in supporting higher education through the Morrill Acts, public higher education appeared to gain a more stable means to support its purposes as a more responsive American university emerged.

\section{References}

1. S. G. Cash (2003), "Private voluntary support to public universities in the United States: An early history," CASE International Journal of Educational Advancement, 4, 1, pp. 65-76.

2. W. B. Leslie (1992), Gentlemen and Scholars: College and Community in the "Age of the University,"

Pennsylvania State University Press, University Park, pp. 1-2.

3. L. R. Veysey (1965), The Emergence of the American University, University of Chicago Press, Chicago, p. 439.

4. Ibid., 305-6; quotation p. 306. See also pp. 302-17.

5. Bureau of the Census (1975), Historical Statistics of the United States, Colonial Times to 1970, part 1, US Bureau of the Census, Washington, DC, p. 8.

6. Ibid., pp. 22.

7. Ibid., p. 11.

8. Ibid., pp. 912-13.

9. J. Hughes and L. P. Cain (1998), American Economic History, 5th edn., Addison-Wesley, Reading, MA, pp. 344-5.

10. F. Rudolph (1990), The American College and University: A History, reprint with an introductory essay and supplemental bibliography by J. R. Thelin, University of Georgia Press, Athens, p. 425.

11. R. H. Bremner (1988), American Philanthropy, 2nd edn., University of Chicago Press, Chicago, p. 106.

12. Ibid., p. 102.

13. Ibid.

14. A. Carnegie (1962), The Gospel of Wealth and Other Timely Essays, ed. Edward C. Kirkland, The Belknap Press of Harvard University, Cambridge, UK, p. 25.

15. Ibid., pp. 32, 35.

16. Bremner (1988), American Philanthropy, op. cit., p. 107.

17. M. Curti, J. Green, and R. Nash (1963), “Anatomy of giving: Millionaires in the late 19th century," American Quarterly, 15, p. 418.

18. Ibid., p. 419.

19. Ibid., pp. 424-5.

20. F. W. Blackmar (1890), The History of Federal and State Aid to Higher Education, Bureau of Education, Circular of Information No. 1, Government Printing Office, Washington, DC, p. 48.

21. Ibid., p. 47.

22. R. Hofstadter and C. DeWitt Hardy (1952), The Development and Scope of Higher Education in the United States, Columbia University Press, New York, p. 40.

23. J. S. Brubacher and W.s Rudy (1997), Higher Education in Transition, 4th edn., Transaction Publishers, New Brunswick, NJ, p. 159.

24. R. L. Geiger (1986), To Advance Knowledge: The Growth of American Research Universities 1900-1940, Oxford University Press, Oxford, p. 6.

25. R. L. Williams (1991), The Origins of Federal Support for Higher Education, Pennsylvania State University Press, University Park, p. 3.

26. Ibid.

27. Blackmar (1890), The History of Federal and State Aid to Higher Education, op. cit., p. 51.

28. M. Curti and R. Nash (1965), Philantbropy in the Shaping of American Higher Education, Rutgers University Press, New Brunswick, NJ, p. 121.

29. C. M. Gates (1961), The First Century at the University of Washington, 1861-1961, University of Washington Press, Seattle, p. 5.

30. University of Washington Libraries (1998), "The University of Washington's early years," available from <http://www.lib.washington.edu/exhibits/site/ early.html $>$.

31. Ibid.

32. H. D. Sheldon (1940), History of University of Oregon, Binfords \& Mort Publishers, Portland, OR, p. 29.

33. Ibid., p. 31.

34. J. Allmendinger (1998), "History of Colorado State University," available from <http:// welcome.colostate.edu/index.asp?url=history_early1>.

35. W. E. Davis (1965), Glory Colorado! A History of the University of Colorado, 1858-1963, Pruett Press, Boulder, CO, pp. 10-13; F. S. Allen, P. I. Mitterling, H. L. Scamehorn, E. Andrade, Jr., M. S. Foster (1976), The University of Colorado, 1876-1976, Harcourt Brace Jovanovich, New York, pp. 23-6.

36. M. Kuhn (1955), Michigan State: The First Hundred Years, 1855-1955, Michigan State University Press, Lansing, p. 5.

37. J. E. Pollard (1952), History of the Ohio State University, Ohio State University Press, Columbus, p. 9.

38. Ibid.

39. Ibid., pp. 10-11. 
40. H. Hale (1948), University of Arkansas, 1871-1948, University of Arkansas Alumni Association, Fayetteville, p. 14.

41. C. S. Griffin (1974), The University of Kansas: $A$ History, University of Kansas Press, Lawrence, p. 25.

42. Ibid., p. 28.

43. W. Sterling (ed.) (1891), Ouarter-Centennial History of the University of Kansas, 1866-1891, George Crane \& Company, Topeka, KS, p. 48.

44. W. U. Solberg (1968), The University of Illinois, 18671894: An Intellectual and Cultural History, University of Illinois Press, Urbana, p. 52.

45. M. Bezilla (1985), Penn State: An Illustrated History, Pennsylvania University Press, University Park, pp. 4-6, 12.

46. R. C. McMath, Jr., R. H. Bayor, J. E. Britain, L. Foster et al. (1985), Engineering the New South: Georgia Tech, 1885-1985, University of Georgia Press, Athens, p. 12.

47. Ibid., p. 18.

48. Ibid., p. 29.

49. D. L. Kinnear (1972), The First 100 Years: A History of Virginia Polytechnic Institute and State University, Virginia Polytechnic Institute Educational Foundation, Blacksburg, pp. 27-37.

50. D. Walker Hollis (1956), University of South Carolina, Vol. II: College to University, University of South Carolina Press, Columbia, p. 97.

51. Ibid., p. 157.

52. A. G. Pickerell and M. Dornin (1968), The University of California: A Pictorial History, University of California Press, Berkeley, p. 19.

53. Ibid., p. 20.

54. V. A. Stadtman (1970), The University of California, 1868-1968: A Centennial Publication of the University of California, McGraw-Hill, New York, p. 108.

55. Ibid., p. 138.

56. Ibid., p. 139

57. Ibid., p. 119.

58. J. Brundage Sears (1990), Philanthropy in the History of American Higher Education, introduction by R. L. Geiger, Transaction Publishers, New Brunswick, NJ, p. 17. 